Vol. 4, No. 1, 2021

\author{
V. L. Starchevskyy, Yu. M. Hrynchuk, P. A. Matcipura, V. V. Reutskyy \\ Lviv Polytechnic National University, \\ Department of physical, analytical and general chemistry \\ e-mail: vstarchevskyy@gmail.com
}

\title{
PHYSICAL AND MECHANICAL PROPERTIES OF ASPHALT CONCRETE OBTAINED FROM BITUMEN MODIFIED BY EPOXIDE OF VEGETABLE ORIGIN
}

https://doi.org/10.23939/ctas2021.01.105

The properties of fine-grained asphalt concrete and its modified by bio based epoxy rape oil (BERO) form were studied. Rapeseed oil epoxide (ROE) obtained from renewable and ecological raw materials, rapeseed oil in a composition with initiators (hardeners) was used as a modifier. It was found that the introduction of BERO in the amount of $3 \%$ of the mass. allows to increase indicators of limit of durability of asphalt concrete at compression at a temperature of $20{ }^{\circ} \mathrm{C}$ and $50{ }^{\circ} \mathrm{C}$. The efficiency of BERO composition and its positive effect on physical and mechanical properties of asphalt concrete is established.

Key words: modified asphalt concrete; epoxy; bitumen; compressive strength.

\section{Introduction}

Bitumen is a binder from which asphalt concrete is prepared and its quality directly depends on the properties of the bitumen on the basis of which they are prepared. Bitumens, in turn, are modified in every way to obtain a better road surface. Among the many additives [1-11] that improve the quality of bitumen and asphalt concrete, known polymers, adhesion promoters, fibers, waxes, rubber crumb, natural bitumen, the most popular modifiers are polymers. They are also divided into thermoplastics, thermoplastics, terpolymers and latexes. Such additives are able to reduce the sensitivity of bitumen to temperature changes, increase the cohesive strength and heat resistance of binders, can give them greater elasticity, as well as improve their behavior at low temperatures. This in turn increases the strength, shear strength and crack resistance of asphalt pavements.

The concept of thermosetting modified epoxy asphalt, has some disadvantages like high cost, oil origin and toxicity. Therefore, this work focuses on the study of the properties of asphalt concrete based on bitumen modified by BERO on the basis of renewable environmental raw materials.

In previous works $[1,6,7]$ it was found that the modification of road bitumens BERO, allows to improve the quality characteristics of road bitumens, such as adhesion, penetration, softening temperature
$[1,6,7]$. At the same time adhesion improves 3 times both to a stone, and to glass. Other qualitative characteristics of bitumen remain practically unchanged, which can positively affect the strength properties of asphalt concrete.

That is why in this work the influence of the modified BERO bitumen with different hardeners on the physical and mechanical properties of asphalt concrete was studied.

\section{Materials and methods of research}

As raw materials were used both - pure petroleum road bitumen brand BND 70/100, and modified with epoxide of rapeseed oil in the amount of $3 \%$ wt., at a temperature of $160{ }^{\circ} \mathrm{C}$ for 2 hours It is proposed to use adipic acid (AA), maleic anhydride (MA) and polyethylene polyamine (PEPA) as hardeners. This choice should show the difference between the properties of the modified bitumen with and without the additive. Characteristics of bitumen modified by BERO, and taken for the formation of samples of asphalt concrete, are presented in Table1.

The grain composition of the asphalt concrete mixture was selected using particle size distribution curves of dense continuous mixtures. The composition of the mineral part of the asphalt concrete mixture picked up according to DSTU BV.2.7-119-2011 (Table 2). The grain composition of the mineral powder is shown in Table 3. 
Characteristics of modified bitumen BERO

\begin{tabular}{|l|c|c|c|c|}
\hline \multicolumn{1}{|c|}{ Bitumen } & $\begin{array}{c}\text { Penetration at } \\
25{ }^{\circ} \mathrm{C}, \mathrm{M} \cdot 10^{-4} \\
(0.1 \mathrm{MM})\end{array}$ & $\begin{array}{c}\text { Softening } \\
\text { point, }{ }^{\circ} \mathrm{C}\end{array}$ & $\begin{array}{c}\text { Adhesion to } \\
\text { glass, } \%\end{array}$ & $\begin{array}{c}\text { Adhesion to crushed } \\
\text { stone, points }\end{array}$ \\
\hline BND 70/100 & 71 & 46 & 29.32 & 2.3 \\
\hline BND 70/100 +BERO +AA & 83 & 47 & 92.26 & 4 \\
\hline BND 70/100 + BERO +MA & 67 & 49 & 35.36 & 4 \\
\hline BND 70/100 +BERO +PEPA & 77 & 47 & 97.91 & 5 \\
\hline
\end{tabular}

Table 2

Composition of asphalt concrete

\begin{tabular}{|l|c|}
\hline \multicolumn{1}{|c|}{ Material } & The content of material in asphalt concrete, $\%$ \\
\hline Crushed stone fr. 15-20 Mм & 6.0 \\
\hline Crushed stone fr. 10-15 Mм & 15.0 \\
\hline Crushed stone screening 5-10 MM & 24.0 \\
\hline Crushed stone screening 0-5 MM & 45.0 \\
\hline Mineral powder & 10.0 \\
\hline Total, \% & 100.0 \\
\hline Bitumen (as a percentage by weight over 100 \% of min. comp.) & 5.5 \\
\hline
\end{tabular}

Table 3

Grain composition of mineral powder

\begin{tabular}{|c|c|c|c|c|c|c|c|}
\hline \multirow{2}{*}{ The diameter of the sieve hole } & \multicolumn{6}{|c|}{ The residual particles on the sieve, $\%$ wt. } & \multirow{2}{*}{$\sum$} \\
\hline & 1.25 & 0.63 & 0.315 & 0.14 & 0.071 & $<0.071$ & \\
\hline Mineral powder & 0 & 0.1 & 1.2 & 4.7 & 12.9 & 81.1 & 100 \\
\hline
\end{tabular}

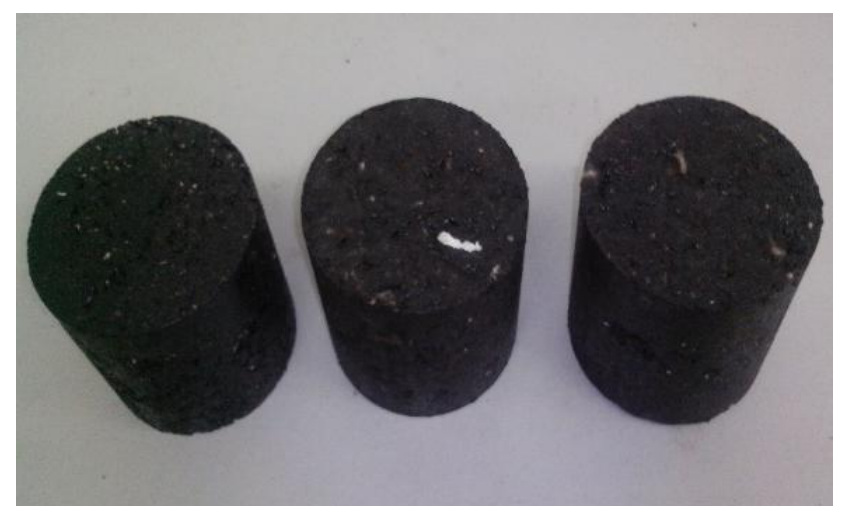

Fig. 1. Photo of samples of asphalt mixtures

Physico-mechanical properties of asphalt concrete mixture were determined on cylindrical samples $(\mathrm{D}=71.4 \mathrm{~mm}, \mathrm{~h}=71.4 \pm 1.5 \mathrm{~mm})$ obtained in laboratory conditions by compaction of mixtures in standard forms [12] (Fig. 1).

\section{Results and discussion}

After forming asphalt concrete samples on the basis of standard and modified bitumens, their physical and mechanical characteristics were determined and changes in the properties of asphalt concrete prepared on the basis of modified BERO bitumen were studied. All tests were performed in the laboratory according to DSTU B B.2.7-89-99. The test results are shown in table 4.

The effect on the compressive strength of asphalt concrete at a temperature of $20{ }^{\circ} \mathrm{C}$ is almost the same for all modified bitumens. And the compressive strength of asphalt concrete at a temperature of $50{ }^{\circ} \mathrm{C}$ already varies depending on the hardener used. Analyzing the obtained results, we observe that BERO is suitable for use as a bitumen modifier. In particular, at a temperature of $20^{\circ} \mathrm{C}$ the highest strength index shows 
asphalt concrete modified BERO in a composition with polyethylene polyamine, while at a temperature of $50{ }^{\circ} \mathrm{C}$ the best strength results show a composition of BERO with maleic anhydride. In general, BERO modified asphalt concrete has higher compressive strength at $20{ }^{\circ} \mathrm{C}$ and $50{ }^{\circ} \mathrm{C}$ (compared to asphalt concrete based on unmodified bitumen). As a result, the cohesive strength of the mixture also increases. This may indicate that they are characterized by greater heat resistance, and asphalt pavements equipped with their use will have greater track resistance in operating conditions.

Table 4

Physico-mechanical characteristics of fine-grained asphalt concrete

\begin{tabular}{|l|c|c|c|c|}
\hline \multicolumn{1}{|c|}{ Index } & $\begin{array}{c}\text { Average density, } \\
\mathrm{g} / \mathrm{cm}^{3}\end{array}$ & $\begin{array}{c}\text { Water } \\
\text { saturation, } \\
\% \text { vol. }\end{array}$ & \multicolumn{2}{|c|}{$\begin{array}{c}\text { Compressive strength, MPa at } \\
\text { temperature }\end{array}$} \\
\cline { 3 - 5 } & 2.37 & 2.8 & $2{ }^{\circ} \mathrm{C}$ & $50{ }^{\circ} \mathrm{C}$ \\
\hline BND 70/100 & 2.37 & 2.3 & 6.5 & 2.2 \\
\hline BND 70/100 + BERO +AA & 2.37 & 3.2 & 6.6 & 2.6 \\
\hline BND 70/100 + BERO +MA & 2.37 & 3.0 & 6.7 & 2.4 \\
\hline BND 70/100 + BERO +PEPA & - & Not more than 3.5 & Not less than 2.7 & Not less than 1.2 \\
\hline $\begin{array}{l}\text { Compliance with } \\
\text { requirementsDSTU B B.2.7-119: } \\
\text { 2011 A-2 }\end{array}$ & & & & \\
\hline
\end{tabular}

It is known about a large number of additives for modification of road bitumens. They are usually good modifiers and are characterized by high physicalmechanical indicators, however, it should be noted that their price is also quite high. The main reason that restrains the increase in the use of asphalt concrete based on modified bitumen is the high cost of modifiers. Their introduction into bitumen increases the cost of the binder by 1.5-3 times.

The use of cheaper additives does not reduce costs due to the required higher content in the mixture. In addition, cheap additives do not provide bitumen with the necessary properties, such as: elasticity, high heat resistance, increased ductility and deformability at low temperatures, etc. [6].

Modification of bitumen by BERO additive is technologically simple, does not require specific equipment and is performed by standard technology, then this additive is cheap and is made on the basis of domestic, cheap, environmentally friendly and renewable raw materials.

Therefore, a modifying additive BERO:

- can improve the physical and mechanical properties of modified bitumens (adhesion, penetration, softening temperature);

- is easy and cheap to use;

- improves properties of asphalt concrete;
- can compete with modern effective foreign analogues.

\section{Conclusions}

The results of research indicate the effectiveness of the additive BERO and its positive effect on the compressive strength, which will increase the durability of the road surface.

Bitumen modified by BERO meets the standards [13]. Its characteristics are preferred for modified bitumens. Asphalt concrete modified with BERO has higher strength values compared to other asphalt concretes.

\section{References}

1. Starchevskyy, V., Hrynchuk, Y., Matcipura, P., Reutskyy, V. (2021). Influence of initiators on the adhesion properties of bitumen modified by natural origin epoxide. Chemistry and Chemical Technology, 15(1), 142-147. doi: 10.23939/chcht15.01.142

2. Demchuk, Y., Sidun, I., Gunka, V., Pyshyev, S., Solodkyy, S. (2018). Effect of Phenol-Cresol-Formaldehyde Resin on Adhesive and Physico-Mechanical Properties of Road Bitumen. Chemistry \& Chemical Technology, Vol. 12, No. 4, 456-461. doi: 10.23939/chcht12.04.456

3. Gunka, V., Demchuk, Yu., Pyshyev, S. et al. (2018). The selection of raw materials for the production of road 


\section{L. Starchevskyy, Yu. M. Hrynchuk, P. A. Matcipura, V. V. Reutskyy}

bitumen modified by phenol-cresol-formaldehyde resins. Petroleum and Coal, Vol. 60, Is. 6, 1199-1206.

4. Gunka, V., Sidun, I., Solodkyy, S., Vytrykush, N. (2019). Hot Asphalt Concrete with Application of Formaldehyde Modified Bitumen. In: Blikharskyy Z., Koszelnik P., Mesaros P. (eds) Proceedings of CEE 2019. CEE 2019. Lecture Notes in Civil Engineering, vol 47. Springer, Cham.

5. Wei, J. and Zhang, Y. (2012). Study on the Curing Process of Epoxy Asphalt, "Journal of Testing and Evaluation”, 40, No. 7, 1169-1176. doi.org/10.1520/ JTE20120136.

6. Hrynchuk, Y., Sidun, I., Gunka, V., Prysiazhnyi, Y., Reutskyy, V., Mosiuk, M. (2019). Epoxide of rapeseed oilmodifier for bitumen and asphalt concrete. Petroleum \& Coal, 61 (4), Vol. 61, Is. 4, 836-842.

7. Hrynchuk, Y., Sidun, I., Gunka, V., Reutskyy, V., Koval, I., Matcipura, P., Mosiuk, M. (2020). Possibility Improvement Technology of Modification Road Bitumen by the Green 3 Epoxy Rapeseed Oil on the Basis of Renewable Raw Material. Petroleum \& Coal, Vol. 62, Iss. 4, 836-842.

8. Demchuk, Y., Gunka, V., Pyshyev, S., Sidun, I., Hrynchuk, Y., Kucinska-Lipka, J., Bratychak, M. (2020).
Chemistry \& Chemical Technology Vol. 14, No. 2, 251256. doi.org/10.23939/chcht14.02.

9. Pyshyev, S., Grytsenko, Y., Solodkyy, S., Sidun, I., Vollis, O. (2015). Using bitumen emulsions based on oxidized, distillation and modified oxidized bitumens for slurry seal production. Chem Chem Technol 9(3):359-366. doi.org/10.23939/chcht09.03.359.

10. Haiyan, Y., Yuge, Zhang, Yifan, Sun, Wei, Xu, Dier, Yu, Hongfeng, Xie. (2015)Performance of hot mix epoxy asphalt binder and its concrete. Materials and Structures. Nanjing, Vol. 48, No. 11, 3825-3835. doi10_1617-S11527-014-0442-0

11. Xinxing, Zhou, Shaopeng, Wu, Gang, Liu, Pan, Pan (2016). Molecular simulations and experimental evaluation on the curing of epoxy bitumen. Materials and Structures. Nanjing, Vol. 49, Is. 1-2, 241-247. https://link. springer.com/article/10.1617/s11527-014-0491-4

12. Sumishi Asfal'tobetonni i asfal'tobeton dorozhniy taaerodromnyy. Metody Vyprobuvan': DSTU BV.2.7319:2016

13. Bitumydorozhniv"yazki, modyfikovani dobavka myadheziynymy. Tekhnichniumovy.SOU 45.2-00018112067:2011

\section{В. Л. Старчевський, Ю. М. Гринчук, П. А. Маціпура, В. В. Реутський Національний університет “Львівська політехніка", кафедра фізичної, аналітичної та загальної хімії e-mail: vstarchevskyy@gmail.com}

\section{ФІЗИКО-МЕХАНІЧНІ ВЛАСТИВОСТІ АСФАЛЬТОБЕТОНУ, ОДЕРЖАНОГО 3 БІТУМУ, МОДИФІКОВАНОГО ЕПОКСИДОМ РОСЛИННОГО ПОХОДЖЕННЯ}

Досліджено властивості дрібнозернистого асфальтобетону та його форми, модифікованої екологічним епоксидом ріпакової олії (BERO). Як модифікатор використано епоксид ріпакової олії (ERO), одержаний із відновлюваної та екологічної сировини, ріпакової олії в композиції з ініціаторами (затверджувачами). Встановлено, що введення BERO в кількості 3 \% мас. дає змогу підвищити показники границі міцності асфальтобетону на стиск за температури $20{ }^{\circ} \mathrm{C}$ та $50{ }^{\circ} \mathrm{C}$. Встановлено ефективність дії композиції BERO та її позитивний вплив на фізико-механічні властивості асфальтобетону.

Ключові слова: модифікований асфальтобетон; епоксидна смола; бітум; міцність на стиск 